\title{
PROBLEMATIC OF THE FUNCTIONAL STRUCTURE OF SLOVENE CITIES
}

\author{
Mirko Pak \\ Pod vrbami I, 1000 Ljubljana, Slovenia \\ e-mail: mirko.pak@ff.uni-lj.si
}

\begin{abstract}
Slovene cities are subject of rapid spatial, structural and functional development. Ljubljana, the capital, is pointing out, where development differences are increasing in comparison to other Slovene cities. The article represents the processes of tertiarisation, spatial changes and changes in the functional structure of Slovene cities.
\end{abstract}

Key words: Slovene cities, functional structure, urban land use, trade centers.

\section{INTRODUCTION}

Introduction of market economy at the end of eighties and in particular in the nineties resulted in functional construction of Slovene cities having been subject to the most signifycant changes: from the quantitative and qualitative point of view, in the structure of their activities, locations and spatial arrangement of these activities. The structure and distribution of individual activities significantly changed the image, as well as social and in particular functional construction of Slovene cities. Increase takes place in the heterogeneous use of city space, heterogeneity in their functional construction and heterogeneity in functional structure. As a consequences of such processes, values of the city space have changed completely. These values used to be similar in the Slovene cities and their parts before the introduction of market economy, however now they are subject to bigger and bigger changes, being within the city as well as among cities. However the most significant increase - up to 1:2 may be noticed when comparing Ljubljana and other Slovene cities.

Post-industrial period, which is in Slovenia in its final phase and, likewise around the world, characterised by globalisation, is primarily oriented towards factors of explicitly economic nature, which is indicated in economic, social and spatial development of cities:

- through the concentration of capital, knowledge, decision-making, workplaces, highly qualified labour force and other infrastructural and over-regional institutions,

- through general tertiarisation, and in production through strengthening of specialisation, 
- through regional centralisation in Ljubljana, on the Coast and within the territory of Maribor,

- through the increased social disparities or bigger segregation, resulting from the above mentioned (Pak, 2003).

\section{QUALITATIVE CHANGES}

In the nineties of the previous century, all Slovene cities were subject to significant increase in the number of service and decrease in the number of production establishments. Big industrial establishments experienced, by the rule, significant ownership, organisational and production changes: division, some of them suspended their operations, some others, the most successful were purchased by foreign capital. As a result the number of industrial workers in Slovenia decreased by half, to about $30 \%$ of all active population.

Industrialisation affected the most old industrial cities with big industrial establishments or with establishments of textile, footwear and similar »critical« industries. More than a half of the active population of old industrial centres such as Maribor, Ravne and Jesenice, used to be employed in industry, however this number was reduced by half. Cities with smaller, heterogeneous and specialised industrial establishments, such as Ljubljana and Kranj, were less affected by the industrialisation. The number of industrial workplaces in Kranj has even not changed from before 1990. However in all cities the number of small manufacturing establishments with only a few employees has increased. Locations of such companies are that of former big industrial establishments, in the so-called trade-industrial zones at the periphery of a continuously built-up city territory, originating already from the eighties, and in new technological parks, which are located also in suburban zones. Such trade or production zone may be found in almost every small city, with the number of workplaces rapidly increasing.

Also other activities, in particular service activities, are subject of brisk development, however rather slowing down during the last years. The number of wholesale and retail outlets as well as hotels and restaurants has been growing rapidly, in the cities as well as in the countryside.

When reviewing development of the number of business entities during the last five years, when their growth has already slowed down, significant differences between Slovene cities may be noticed. The number of business entities after 1990 was increasing the most in Ljubljana and partly in nearby settlements of the Ljubljana urban region and in cities of the Slovene Primorje. Rapid growth of such activities in Ljubljana is a results of the central state function and the highest concentration of capital, functions and people. Similar development trends in coastal cities Koper, Piran, Izola and Portorož were mostly due to the closeness of the Italian border, which has been completely opened for at least forty years, closeness of Trieste and brisk tourism. The number of business entities in all other Slovene cities have been stagnating or even regressing over the last five years. (Table 1). 
Table 1: Development of the number of business entities 1997 - 2002 in \%.

\begin{tabular}{lrrr}
\hline & $1997 / 1999$ & $1999 / 2002$ & $1997 / 2002$ \\
\hline Ljubljana & 11,3 & $-1,9$ & 9,2 \\
Maribor & $-5,3$ & $-5,0$ & $-10,4$ \\
Kranj & 4,9 & $-1,7$ & 3,1 \\
Celje & 6,9 & $-6,0$ & 0,4 \\
Velenje & 4,9 & 1,8 & 6,8 \\
Koper & 6,3 & $-6,0$ & 0,2 \\
Novo mesto & $-9,4$ & $-4,9$ & $-13,9$ \\
Cities with over 20,000 inhabitants & 6,1 & $-1,9$ & 4,2 \\
Cities with 10 to 20,000 inhabitants & $-4,9$ & $-5,1$ & $-9,7$ \\
Republic of Slovenia & 6,3 & $-3,2$ & 2,9 \\
\hline
\end{tabular}

Source: Statistical Yearbook 1998, 2000 and 2002, Republic of Slovenia, Ljubljana.

Table 1 indicates differences between the seven the biggest Slovene cities as regards increasing number of business entities. Big differences which may be noticed between the two periods are the result of development selection, when significant increase in the first half of the nineties was followed by rationalisation, especially after 2000 .

In bigger cities the increase in the number of business entities is much more favourable, however the ten small cities with 10,000 to 20,000 inhabitants experience consequences of the rapid increase in the past years, resulting in significant decrease in the number of business entities. Therefore economic performance of such cities is less powerful and development slower. However the number of service activities in smaller local centres, in particular suburban zones, still increases. Stronger suburbanisation is associated with the increasing number of workplaces in suburbs. Within the period $1996-2000$ the number of workplaces in the suburban area of Ljubljana increased up to $25 \%$ ( Ravbar, 2002).

Business entities are predominated by manufacturing (I), wholesale and retail trade (II), financial and business activities (III) and other social and personal services (IV) (Table 2).

Table 2: Differences in the number of the most frequent business entities in the period $1997-2002$ in \%.

\begin{tabular}{lrrrc}
\hline & \multicolumn{4}{c}{ Group of plant } \\
\hline Cities with over 20,000 inhabitants & \multicolumn{1}{c}{ I } & \multicolumn{1}{c}{ II } & \multicolumn{1}{c}{ III } & IV \\
Cities with 10 to 20,000 inhabitants & $-9,8$ & $-23,3$ & 11,7 & 58,8 \\
Republic of Slovenia & $-12,8$ & $-19,5$ & 1,1 & 23,6 \\
\hline
\end{tabular}

Source: Statistical Yearbook 1998 and 2003, Republic of Slovenia. Ljubljana.

Since the number of manufacturing establishments and wholesale and retail outlets has increased significantly after 1990, the regression thereof in the last years was due to sheer 
economic reasons. A number of manufacturing establishments, started to operate after 1990 mostly on locations of former big industrial companies, were closed down due to false expectations and investments, and numerous wholesale and retail outlets due to the competitiveness of new big wholesale and retail outlets and trade centres. Table 2 indicates increase in the number of various business and non-business activities (groups III and IV), which is more rapid in bigger than in smaller cities. Concentration is always oriented towards bigger cities and their suburban zones. The first place in this process is occupied by Ljubljana with $13,3 \%$ of the Slovene inhabitants and $20,6 \%$ of total business entities.

In general, growth in the number of activities in Slovene cities has slowed down. For example, the number of wholesale and retail outlets in Ljubljana has increased for almost two times within the period $1989-1999$ and the number of employees thereof merely for $10 \%$. Markets, other wholesale and retail outlets and trade centres, built most frequently at the city outskirts, resulted in Ljubljana in the doubled area of the sales surface per inhabitant. On account of mega and hipo markets which are established by the biggest trade company Mercator, over 200 small wholesale and retail outlets were closed down, most of them in city centres (Pak, 2001).

In Ljubljana a number of small supply centres developed already in the middle of nineties. However these are passing through a crisis due to small surfaces, limited selection of goods, lack of parking places, unfavourable location and other factors. In the meantime they were lagged behind by hipermarkets and big trade centres. BTC (Blagovno trgovski center) (Merchandise Trading Centre) occupies a special position, being a real shopping city and one of the biggest trade centres in this part of Europe. It includes more than 300 shops with the total surface of $361,000 \mathrm{~m}^{2}$, over $70,000 \mathrm{~m}^{2}$ of sales surfaces and over 3,000 employees. It includes also a number of banks, restaurants, trade and other service establishments and an increasing leisure area (Pak, 2001; Drozg, Pak, 2001, Drozg, 2001 a in Drozg 2001 b).

Generally speaking service activities and trade centres are development in almost all 60 small cities, until 1995 former centres of the at-that-time big municipalities. However service activities are developing rapidly also in new municipal centres, since the number of municipalities has increased up to 193 after the reform in 1995.

Activities which experience the most rapid increase are financial and business activities (III) and social and personal services (IV), which follow the social-economic development of Slovenia and Slovene cities. Rapid increase of these activities during the last years is shown in Table 2, in particular in cities with over 20,000 inhabitants, which are important regional centres. Functions, situation and character of these cities are signified by great differences, for example Ljubljana and Maribor. Within the period $1997-2002$ the number of financial and business activities (III) increased in Ljubljana for $25 \%$ and in Maribor only for $13,4 \%$, and the number of other activities (IV) in Ljubljana for $77,5 \%$ and in Maribor for $33,5 \%$. This is correspondingly associated with the concentration of highly qualified labour force. This shows the administrative and business concentration in Slovene cities, with Ljubljana pointing out. 
Economic concentration is crucial which, mostly inherited, has strengthen after 1990, spread in its substance and became internationalised. Ljubljana hosts registered offices of almost a half of Slovene banks (13), Maribor of only 3 and other bigger cities of one at the most. The situation is similar as regards foreign representative offices and companies. In 1990 three companies were registered in Ljubljana which were in foreign ownership and 144 joint ventures, however the numbers in 1996 amounted to 395 and 1599. Registered offices of one half of the foreign companies were located in the city centre ( Pak, 1999).

Figure 1: Example of the functional land use in the North Part of Ljubljana

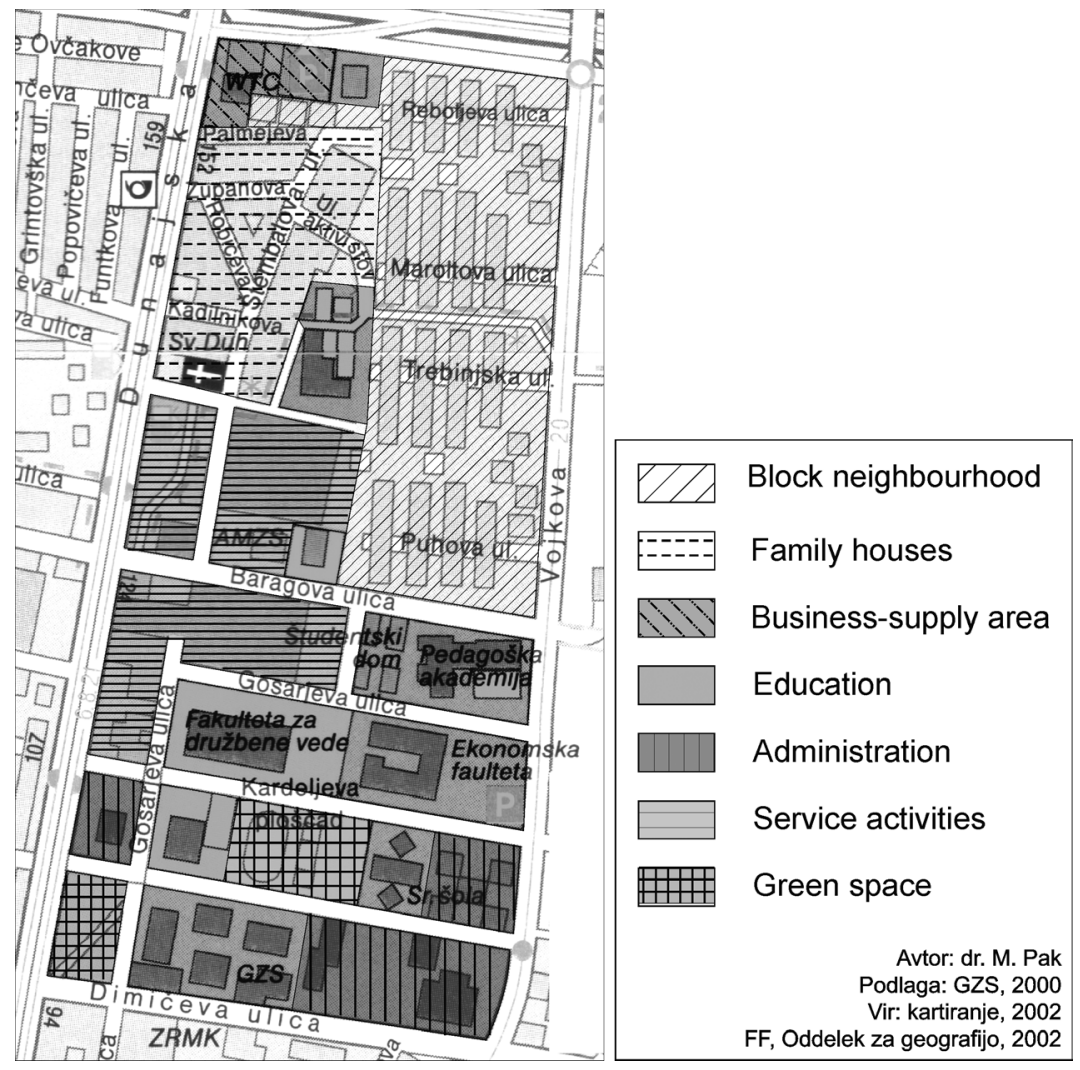

Activities in Slovene cities are in general located without following any model, usually only with regard to available space. This results in significant dispersion in the city space, pressure on free surfaces being extremely high. The deciding factor is financial capability of investor. New urbanistic plans do namely not determine any more a detailed intended use of the space. This results in very heterogeneous business zones, the character of which being mostly of business - production zones. This most often incorporates also the residential function. 
The tertiarisation process of city centres on the account of residential function is standing out. Tertiarisation is associated with new constructions, which are denser and higher, with the decrease of green surfaces and dehumanisation of city centre. The narrower city centre is considered to be occupied by specialised activities however not being able to compete due to the "competition from periphery".

Central-peripheral location of activities represents a serious problem. Development of activities at city's outskirts is disadvantageous for city centres, just as development of big and even bigger, better equipped and more complex centres at outskirts represents disadvantage not only for small establishments but also for isolated bigger establishments.

As evident from the recent researches the motive to visit the centre of Ljubljana or Maribor are some urgent business to be done or even an urgent passage through the centre, the buying occupying only the third place.

Various activities are established also along main traffic roads, especially in the areas of free space. These are usually numerous service activities, as along Tržaška and Dunajska street in Ljubljana. Such parts are usually characterised by functional heterogeneity and incorporate also the residential function.

From the functional point of view, there are two processes associated with the formation of a city's organism. The first signifies new functional breakdown, new relations between centre and outskirts and also formation of a suburbanisation zone in the function of residency and work. New supply and service centres with the highest daily concentrations of inhabitants are formed. Cities, in particular bigger ones, are constituted of more "functional centres".

\section{CONCLUSION}

Functional composition of Slovene cities is undoubtedly still subject of intensive transformation with significant disparities among individual cities. Slovenia is represented mostly by small cities which are in much more difficult situation as regards their economic basis, than bigger cities.

Use of the city space becomes more and more heterogeneous. This holds good in particular for residential districts, having been in the past rather functionally and socially homogeneous. Due to construction technology and changed attitude towards social environments elite objects are possible to be built also on physically worse and socially disadvantageous locations. However the increasing functional heterogeneity and traffic flows cause degradation of some residential districts of high value. The consequence is lost of interest for living in such areas, ageing of inhabitants and decrease in prices.

Finally, I will give a typical example of degradation of the residential area Murgle which is located only a few hundred metres from the centre of Ljubljana. Figure 2 represents nuisance activities, surrounding the "Garden city" with more than 1,000 atrium houses. Following the surveys, this is the reason why the residential settlement, which used to be of the highest reputation, has lost its value already some years ago (Pak, 2003). 
Figure 2: Degradation elements of the residential district Murgle in Ljubljana

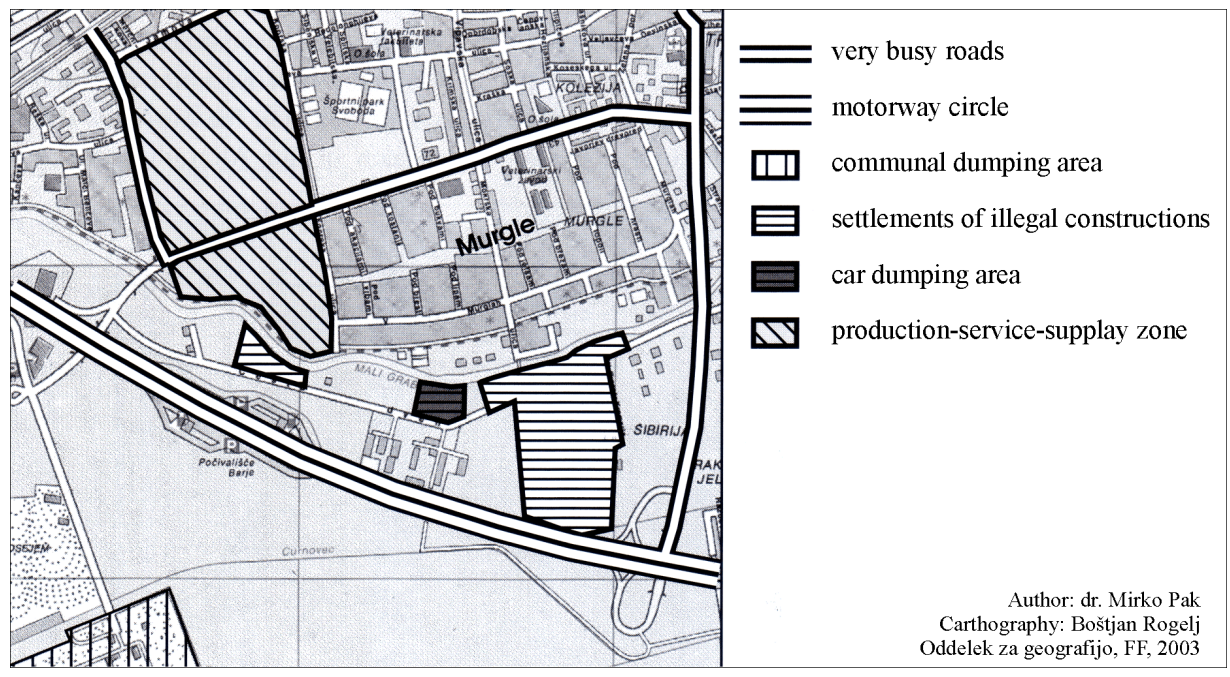

Second example are villas which were built before the second world war at the city centre's outskirts. These are nowadays mostly occupied by business subjects and administrative activities, which is associated also with foreign capital and other elements of globalisation. Slovene cities could still be characterised by strong transition as regards the use of space, with market value, which has been neglected for many years, becoming the basic element.

\section{Literature}

Drozg, V., Pak, M., 2001: Einkaufszentren in Slowenien. Arbeitsmaterial, Akademie für Raumforschung und Landesplanung 282, Hannover, 187-191.

Drozg, V., 2001a: Nakupovalna središča v Sloveniji. Geografski vestnik 73-1, Ljubljana, 9-21.

Drozg , V., 2001b: Versuch der bestimmung eines Entwicklungskonzepts von Einkaufszentren in Slowenien. Arbeitsmaterialien zur Raumordnung und Raumplanung 204, Bayreuth, 81-92.

Pak, M., 1999: Globalisation and development of Slovene Cities. Dela 14, Ljubljana, 131-135.

Pak, M., 2001: Raumordnungspolitische und planungspolitische Behandlung des Einzelhandels in Slowenien. Arbeitsmaterial, Akademie für Raumforschung und Landesplanung 282, Hannover, 183-185.

Pak, M., 2002: Funkcijska zgradba Ljubljane. Geografija Ljubljane, Ljubljana, 131-149.

Pak, M., 2003: Functionale Probleme der Stadtstruktur Sloweniens. Rhein - Mainische Forschungen 124, Frankfurt am Main, 17-27.

Ravbar, M., 2002: Suburbanizacijske težnje v razvoju prebivalstva in delovnih mest v Ljubljani. Geografija Ljubljane, Ljubljana, 213-233.

Statistical Yearbook 1998, 2000 and 2003. Republic of Slovenia. 